\title{
URBAN GROWTH TILL THE YEAR 2000 AND NATIONAL POLICY IN BANGLADESH
}

Bangladesh is a relatively new state organism which is characterized by the low level of urban development as well as by a rapidly increasing percentage of urban population.

In 1974 , urban population constituted hardly $8.8 \%$, in $1981-15.5 \%$, while in 1990, according to the estimates, it amounted to $24.4 \%$ of total population of Bangladesh. ${ }^{1}$ The average yearly growth rate of urban population in the years $1961-1981$ was $8.4 \%$, while in the period between the two censuses (1974-1981) - 11.2\%. According to the estimates, in the decade 1981-1991 it amounted to $7.0 \%$. In 1981, out of the total number of 453 towns, there were 77 municipal centres (pourashavas), whereas in 1991 their number increased to 95 .

The accelerated urban growth in Bangladesh, results in a gradually increasing urban network, extension of the area of the old and emergence of the new zones of rapidly developing urban settlement.

Forecasts regarding the increase of total population number as well as that of urban population and its growth rate in the years 1990-2000 were made by the Bangladesh Planning Commission and by the Urban Development Directorate, as well as by the International Bank for Reconstruction and Development. Assuming that the average annual growth of total population will maintain at the level of $1.9 \%$, the Bangladesh population in 1995-1996 is likely to amount to $122.2 \mathrm{mln}$, and in 1999-2000 — to $128.5 \mathrm{mln}$.

It has been estimated that the average yearly growth rate of urban population in these years will amount to $4.24 \%$ and $3.44 \%$ respectively, while its number will total 32.9 and $38.1 \mathrm{mln}$ respectively.

Similar forecasts were made by the experts of the World Bank and of the Center for Population Studies of Harvard University (U.S.A.). According to their opinion, if the birth rate (41.4 per mille) and death rate (14.7 per mille)

\footnotetext{
${ }^{1}$ A successive general population census was conducted in March 1991. Its data have not been published so far. Incomplete data on urban problems of the recent decade can be found in the Statistical Pocket Book of Bangladesh 1991, published in September 1991, and in the Preliminary Report Population Census, 1991; Bangladesh Bureau of Statistics.
} 
maintain at the present level, Bangladesh population will total $150 \mathrm{mln}$ in 2000. In view of the declining trend of the population growth rate, most economists predict that in 2000 Bangladesh will have 139.7 mln inhabitants. (The 1991 census showed that the country had $108.8 \mathrm{mln}$ inhabitants.)

Forecasts for population growth and for urban development find reflection in the economic plans of Bangladesh. The predictions do not clash with country's priorities comprising agricultural and rural development as the leading sectors in Bangladesh economy.

A feature which is consistent with the regularity of the urban development in Asia is above all growth of large towns. In Bangladesh, towns exceeding one million in 1990 had $47 \%$ of total urban population. Towns having more than one hundred thousand inhabitants occupy an exceptional position in the country's urban development, since the concentration of investment in industry and services makes them attractive multi-functional centres.

Bangladesh differs from other South Asian and South-East Asian countries in that it has a large number of middle-sized and small towns. However, the percentage of population of these towns has recently shown a declining trend.

Visible changes, especially in the case of small towns, did not occur until 1981 due to the raising of the majority of administrative centres upazila (administrative unit of the fourth order until 1981 called thana to the rank of a town. But the economic potentialities of these towns still remain very modest. Left without external assistance, they are incapable of creating and performing modern urban functions.

Municipal towns (pourashavas) are the urban centres of great economic importance (apart from their administrative functions). Assuming that urban development trends of the period 1974-1981 will be continued, these towns are likely to have $46 \mathrm{mln}$ inhabitants in the year 2000 (some $64 \%$ of urban population) as compared to $9.4 \mathrm{mln}$ in $1981(71.2 \%)$.

The three consecutive largest towns in Bangladesh, that is Dhaka, Chittagong and Khulna (Fig. 1), may reach 12.0, 4.6 and $1.6 \mathrm{mln}$ inhabitants respectively, while the further towns: Comilla, Mymensingh, Barisal, Jessore, Pabna, Rajshahi and Rangpur from 200 to 500 thousand (some of them may even exceed this figure, for example Jessore -929 thousand).

The estimates also reveal the growth of towns with the population number 50-100 thousand from 50 to $100 \%$.

Continuation of trends of urban development in the period 1971-1981 may cause the increase in the number of towns having more than 500 thousand inhabitants from 3 in 1981, 4 in 1990 to 7 in 2000.

Assuming the growth rate of municipal centres in the years 1974-1981 to be the index for all towns, the number of urban population was calculated by town size classes for the decades 1980-1990 and 1990-2000 (Table 1).

Data enclosed in Table 1 show that in 2000 in the distinguished classes of towns: below 50 thousand, 50-100 thou., 100-500 thou. and above 500 
thou. the percentage of urban population is likely to amount to $31.2,10.6$, $\mathbf{1 1 . 8}$ and 46.4 respectively. Characteristically, a high percentage of population in the largest towns and in the towns below 50 thou. inhabitants has been maintained. However, it should be said that these estimates are purely theoretical.

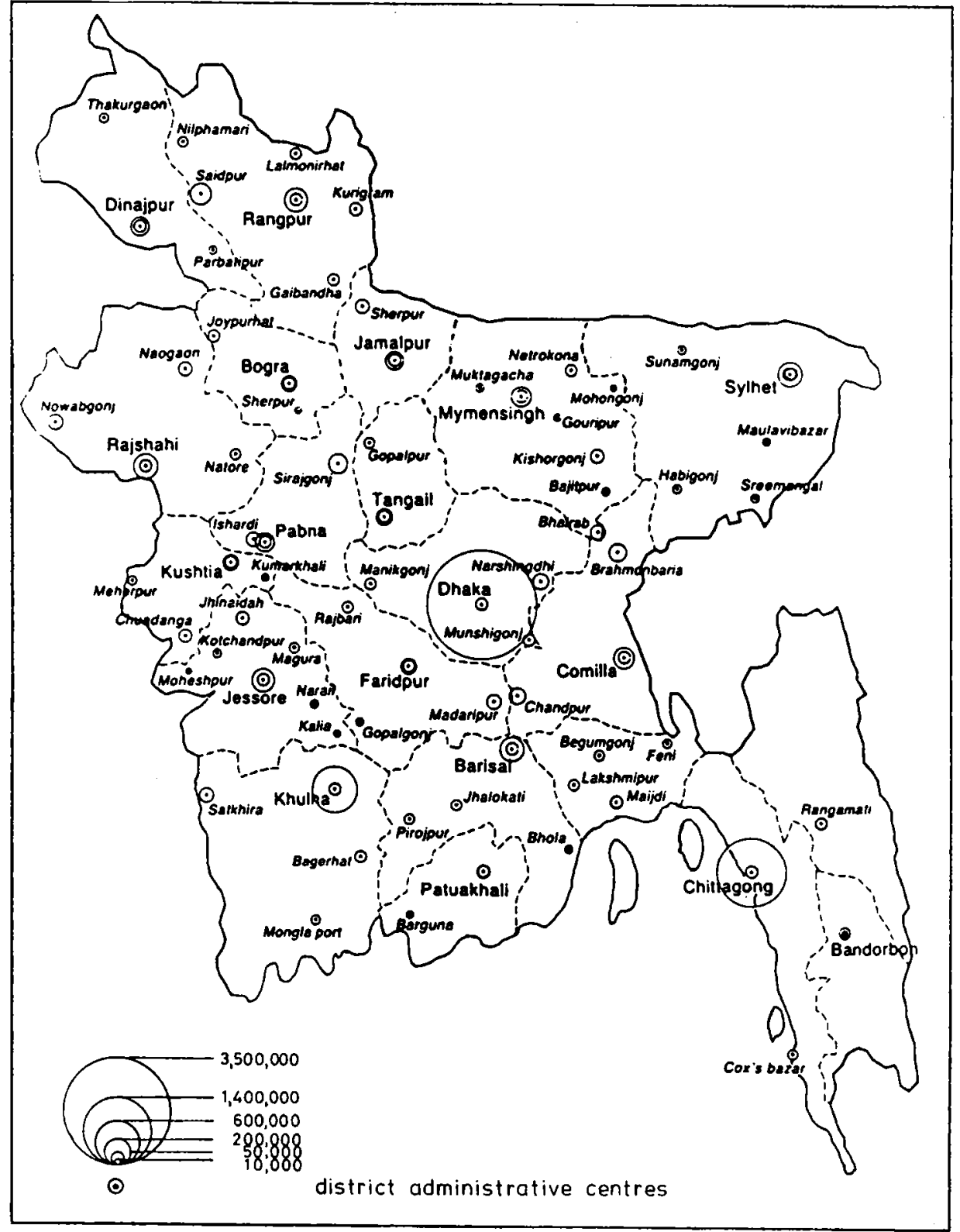

Fig. 1. Distribution and size of municipal towns of Bangladesh in 1981 Source: data of the Bangladesh Bureau of Statistics 
Urban population by classes of town size

\begin{tabular}{|c|c|c|c|c|c|c|c|c|c|c|c|}
\hline \multicolumn{4}{|c|}{1981} & \multicolumn{4}{|c|}{1990 (forecast) } & \multicolumn{4}{|c|}{2000 (forecast) } \\
\hline 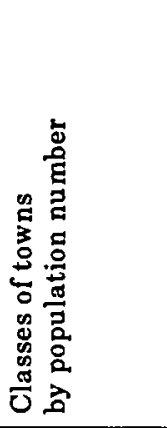 & 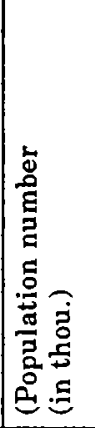 & & & 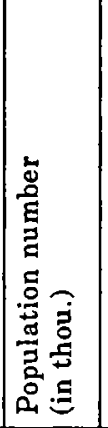 & 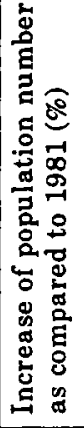 & $\begin{array}{ll}8 \\
0 \\
0 \\
0\end{array}$ & & 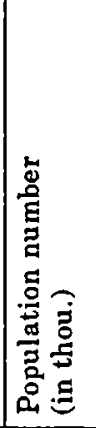 & 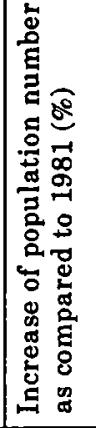 & 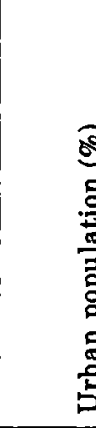 & \\
\hline$>500000$ & 5470 & 42 & & 10522 & 92.4 & 43.8 & & 21768 & 297.9 & 46.4 & \\
\hline $\begin{array}{l}100000- \\
499999\end{array}$ & 1370 & & 52 & 2653 & 93.7 & 11.0 & 54.8 & 5529 & 303.5 & 11.8 & 58.2 \\
\hline $\begin{array}{l}50000- \\
99999\end{array}$ & 1615 & 12 & & 2747 & 70.0 & 11.4 & & 4957 & 206.9 & 10.6 & \\
\hline$<49999$ & 4773 & 36 & & 8119 & 70.0 & 33.8 & & 14649 & 206.9 & 31.2 & \\
\hline $\begin{array}{l}\text { Total } \\
\text { urban } \\
\text { population }\end{array}$ & 13228 & 100 & & 24041 & 81.8 & 100.0 & & 46903 & 254.6 & 100.0 & \\
\hline
\end{tabular}

The system of decentralization of administration carried into effect in recent decades may cause the maintenance of the growth rate of urban population. Its decrease may be prevented solely by changes in agriculture, limiting the migration movement from rural to urban areas or keeping balance between the magnitude of labour force and absorptive capacity of urban centres in the domain of employment. Growth of towns may also be hampered due to their full absorption capacity. These phenomena are usually interrelated. Channeling rural migration to small towns requires, apart from preparation of appropriate technical and social infrastructure determining their development, adequate funds for launching development programmes.

Dhaka with its long-term estimation of the population number is a typical example of a "large city" of a developing country. It is also an example of incredible - in terms of the Third World countries - development of the urban centre. Over the past 40 years its population increased by $10.8 \%$ yearly on the average amounting to: 557,000 in $1961,1,679,572$ in 1974, $3,458,602$ in 1981 , and $6,105,160$ in 1991 . In 1981 , Dhaka had $26 \%$ of total urban population of the country, in $1990-38 \%$. In 1991, Dhaka was three times larger than Chittagong, a second urban centre in the Bangla-desh 
settlement network. The rate of increase is low in comparison with some other South Asian and South-East Asian countries. ${ }^{2}$ The lack of any migration restrictions and a very high birth rate cause that Dhaka will be among the largest South Asian cities in the coming years. The city is situated in an agricultural region specialized in cultivation of jute, cotton, rice, wheat, vegetables and citrus fruits, which in view of the lack of larger mineral resources, may lead to serious economic and social difficulties.

One of the problems of key importance is the city periphery. The areas with haphazard and primitive development provide shelter for nearly 1.5 mln population of the capital city. Density of population in these districts is very high, often amounting to 150 thou. per square $\mathrm{km}$. The problem of these areas, which should be considered in a wider aspect and not only the economic one, has to be taken into account in the city development plans.

The vision of a 12-million Dhaka in 2000 is one of the most difficult urban problems faced by the country. Consistent implementation of the assumptions of decentralization policy may prevent the deepening of the existing difficulties.

In accordance with the assumptions of the five-year economic plan (1986-1990), 1000 centres were chosen to which state investment is to be allocated in the first place. The gradual development of these centres, coupled with better social services and infrastructure is hoped to contribute to the levelling of inter-regional differences. It is expected that after some time some of these centres will acquire a city status (The Third Five-Year Plan, Planning Commission, Dhaka).

The future will show if the chosen road of acceleration of urban development in the coming years appears to be real. Today it may be said that without foreign aid it will not be feasible.

On the basis of geographical and economic conditions estimates can be made regarding the number of urban centres, taking into account the needs of the population, particularly peasants for whom they should be a base of supplies. Retail sale of the necessities for agriculture, as well as a market for rural manufacture and assistance from social service would provide a basis for urban-rural ties. As the experiences of other countries show (Brush, Bracey, 1955), the town should be accessible to the nearby rural inhabitants within one-hour marching distance, that is $4.5-5 \mathrm{~km} .^{3}$ Assuming that a boundary of influence is a square, we obtain the area of $93 \mathrm{sq.km}$. The river systems, forests, the area of Chittagong Hill Tracts, as well as the land occupied by urban development, reduce the area of Bangladesh by some 40 thou. sq.km. Therefore, the area of 104 thou.sq.km. should have

\footnotetext{
${ }^{2}$ For example in Thailand, Bangkok concentrates $57 \%$ of urban population and is almost 24 times bigger than Chiang Mai, the second largest urban centre.

3 At present, this applies to the Third World countries with a poorly developed communication system.
} 
1,118 towns having the area of influence of 93 sq. $\mathrm{km}$ each. The particular urban centres would be bases of supplies for 90 thou. rural population. The above considerations are purely theoretical since the town size and location of towns should stem from their functions for the benefit of a given region.

The environment of Bangladesh is not homogeneous. The middle part of the delta of Ganges and Brahmaputra is flooded for more than six months in a year, which causes considerable difficulties for the settlement. Moreover, a gradual improvement in the system of transport should expand the zones of influence of the particular towns. Thus, it seems that a hypothetical number of 1,000 urban centres in 2000 is too large as compared to real needs and possibilities stemming from physico-geographical conditions.

According to the assumptions of the Planning Commission, it is expected that in 2000 Bangladesh will have 900 towns with 5-50 thou. population, 50 towns with more than 100 thou. inhabitants, 13 towns with over 500 thou. inhabitants, and 7 towns in which population will exceed one million. These towns will require immense capital outlays, new forms of organization, as well as competent administrative service. In view of the country's financial difficulties, this seems unlikely to be achieved by 2000 .

Acceleration of town development is inevitable. It should apply in the first place to medium-sized and small towns. Whether the current growth rate of towns will maintain at the same level, will largely depend on the country's economic development, and especially on industrial development.

According to the UN experts in town planning (UNCHS 1979), changes in the spatial urban settlement system may follow three directions:

- variant I is related to the present-day system; it is based on the settlement network stemming from historical circumstances;

- variant II takes into account the development of the area spreading from Mymensingh in the north to Chandpur in the south. Thus, the management of a new zone of a developing urban settlement would run along the north-south axis. Towns situated to the east and to the west of this zone, functionally tied up with towns in the central area, would have more advantageous conditions of development. This system, resembling the "spine" and the "ribs", might also change the current picture of the density of population in Bangladesh;

- variant III envisages the weakening of the dominant position of Dhaka and its surroundings to the advantage of external regions which are not so densely populated. Thus, the centre of gravity of the economic life would gradually move towards the peripheries. Therefore, the acceleration of economic and urban development processes would occur in the following areas: Dinajpur - Rangpur; Kushtia - Jessore - Kulhna; Sylhet Habigonj Comilla - Feni - Chittagong.

Under the above-mentioned variants, other conceptions, closely related to them, might also be possible. In accordance with the adopted policy of 
decentralization, the area of Dhaka and its vicinity should only marginally be considered in the further development programmes.

Bangladesh, which is facing acceleration of the economic and urban development, should follow the experience of other countries. But its urbanization in the future will largely depend on the course of political, economic and social change in the country.

\section{REFERENCES}

Bangladesh Bureau of Statistics, Bangladesh Population Census 1981, National Series, Analytical Findings and National Tables, Dhaka, Aug. 1984.

Bangladesh Bureau of Statistics, 1991, Statistical Pocket Book of Bangladesh 1991, Dhaka, September 21.

Brush J.E., Bracey H.E., 1955, Rural Service Centres in Southwest Wisconsin and Southern England, Geographical Review 45.

Government of the People's Republic of Bangladesh, Planning Commission, The Third Five-Year Plan: July 1985 - June 1990, Bangladesh Government Press, Dhaka.

United Nations Centre for Human Settlements, 1979, Bangladesh National Physical Planning Project, Urban Development Directorate, Government of Bangladesh, Population Distribution and Growth in Dhaka and Surrounding Areas (1961,1974), Dhaka. 
